\title{
The Principle of Mutual Recognition in European Administrative Law: Still Alive and Kicking?
}

Citation for published version (APA):

Dorigo, S., Eliantonio, M., \& Lanceiro, R. (2020). The Principle of Mutual Recognition in European Administrative Law: Still Alive and Kicking? Review of European Administrative Law, 13(3), 183-195. https://doi.org/10.7590/187479820X16009285510467

Document status and date:

Published: 01/01/2020

DOI:

10.7590/187479820X16009285510467

Document Version:

Publisher's PDF, also known as Version of record

Document license:

Taverne

\section{Please check the document version of this publication:}

- A submitted manuscript is the version of the article upon submission and before peer-review. There can be important differences between the submitted version and the official published version of record.

People interested in the research are advised to contact the author for the final version of the publication, or visit the DOI to the publisher's website.

- The final author version and the galley proof are versions of the publication after peer review.

- The final published version features the final layout of the paper including the volume, issue and page numbers.

Link to publication

\footnotetext{
General rights Owners
rights.

- You may freely distribute the URL identifying the publication in the public portal. please follow below link for the End User Agreement:

www.umlib.nl/taverne-license

Take down policy

If you believe that this document breaches copyright please contact us at:

repository@maastrichtuniversity.nl

providing details and we will investigate your claim.
}

Copyright and moral rights for the publications made accessible in the public portal are retained by the authors and/or other copyright owners and it is a condition of accessing publications that users recognise and abide by the legal requirements associated with these

- Users may download and print one copy of any publication from the public portal for the purpose of private study or research.

- You may not further distribute the material or use it for any profit-making activity or commercial gain

If the publication is distributed under the terms of Article $25 \mathrm{fa}$ of the Dutch Copyright Act, indicated by the "Taverne" license above, 


\title{
The Principle of Mutual Recognition in European Administrative Law: Still Alive and Kicking?
}

\author{
Stefano Dorigo \\ Associate Professor in Tax Law, University of Florence \\ Mariolina Eliantonio \\ Professor of European and Comparative Administrative Law and Procedure, \\ Maastricht University \\ Rui Lanceiro* \\ Assistant Professor in Public Law, University of Lisbon
}

\section{Introduction}

It all started with a bottle of liquor. ${ }^{1}$ The birth of the principle of mutual recognition is often associated with the Cassis de Dijon ruling, in which the Court of Justice held that products that have been lawfully produced and marketed in one Member State should be allowed to be sold in other Member States. ${ }^{2}$ Since the Cassis de Dijon ruling, mutual recognition has become a true 'cornerstone' of the European single market, and, more recently, of the 'area of freedom, security and justice'.

Mutual recognition is not unique to the EU legal system and has indeed been studied from the perspective of international regulatory cooperation and WTO law. ${ }^{3}$ At the EU level, mutual recognition has been extensively studied in

* DOI 10.7590/187479820X160092855104671874-7981 2020 Review of European Administrative Law

This special issue is the output of a workshop organized by the Network of Transnational Administrative Law and held at Maastricht University (Campus Brusssels) in December 2018.

1 'Who has never tasted Kir Royal, an elixir that combines Champagne and the French liquor Cassis de Dijon? The European law story told in this chapter starts from the shocking fact that until 1979, not a soul had been allowed to experience the joys of Kir on German soil.' K Nicolaidis, 'The Cassis Legacy: Kir, Banks, Plumbers, Drugs, Criminals and Refugees' in F Nicola and B Davies (eds), EU Law Stories (Cambridge University Press 2017) 278.

2 Case 120/78 Rewe-Zentraal AG v Bundesmonopolverwaltung für Branntwein [1979] EU:C:1979:42, para 14 .

3 See eg K Nicolaidis and G Shaffer, 'Transnational Mutual Recognition Regimes: Governance without Global Government’ (2005) 68 Law and Contemporary Problems 263; JHH Weiler, 'Mutual Recognition, Functional Equivalence and Harmonization in the Evolution of the European Common Market and the WTO' in F Kostoris Padoa-Schioppa (ed), The Principle of Mutual Recognition in the European Integration Process (Palgrave Macmillan 2005) 25ff; A Correia de Brito, C Kauffmann and J Pelkmans, 'The contribution of mutual recognition to international regulatory co-operation' (2016) OECD Regulatory Policy Working Papers 2/2016 $<$ http://dx.doi.org/10.1787/5jm56fqsfxmx-en> accessed 5 September 2020. 
connection with the internal market, ${ }^{4}$ with studies identifying its shortcomings and intrinsic limitations, ${ }^{5}$ including from an economic perspective. ${ }^{6}$ In parallel, mutual recognition has been examined from the point of view of regulatory pluralism and the conflict of laws between different Member States. ${ }^{7}$ Because of its growing importance beyond the internal market, mutual recognition has also been studied in connection with the area of freedom, security and justice. ${ }^{8}$ Moreover, legal scholarship has compared the behaviour of mutual recognition within these different policy areas. ${ }^{9}$

Mutual recognition embodies a certain Weltanschauung, mixing mutual trust and cooperation, and has rightly been regarded as a 'governance strategy' for European integration, ${ }^{\circ}$ which gives regulatory precedence to 'home state' control over the possibility of harmonization of substantive or procedural requirements for market entrance or a system of control by the 'host state'. " From

4 See eg C Janssens, The Principle of Mutual Recognition in EU Law (OUP 2013); K Armstrong, 'Mutual Recognition' in C Barnard and J Scott (eds), The Law of the Single European Market (Hart 2002) 225.

5 S Weatherhill, 'The principle of mutual recognition: it doesn't work, because it doesn't exist (2018) 43 European Law Review 224; M. Möstl, 'Preconditions and Limits of Mutual Recognition' (2010) 47 Common Market Law Review 405; Nicolaidis (n1) 278; K. Nicolaidis, 'Trusting the Poles? Constructing Europe through mutual recognition' (2007) 14 Journal of European Public Policy 682; J Pelkmans, 'Mutual Recognition: economic and regulatory logic in goods and services' in T Eger and HB Schäfer (eds), Research Handbook on the Economics of European Union Law (Edward Elgar 2012) 113-145; J Pelkmans, 'Mutual recognition in goods. On promises and disillusions' (2007) 14 Journal of European Public Policy 699.

6 J Pelkmans, 'Mutual Recognition in Goods and Services: An Economic Perspective' in PadoaSchioppa (n3) 85-128.

7 See eg K Nicolaidis, 'Mutual Recognition of Regulatory Regimes: Some Lessons and Prospects' (1997) Jean Monnet Working Papers 7/1997<https://jeanmonnetprogram.org/archive/papers/97/97-07.html> accessed 5 September 2020.

8 K Lenaerts, 'The Principle of Mutual Recognition in the Area of Freedom, Security and Justice' (2015) 3 Il Diritto dell'Unione Europea 525; Janssens (n4); W van Ballegooi, The Nature of Mutual Recognition in European Law: Re-examining the notion from an individual rights perspective with a view to its further development in the criminal justice area (Intersentia 2015).

9 Janssens (n4); van Ballegooi (n8).

10 S Schmidt, 'Mutual recognition as a new mode of governance' (2007) 5 Journal of European Public Policy 667. This has also been powerfully restated by the European Commission, 'Mutual recognition in the context of the follow-up of the action plan for the single market' (Communication) COM (99) 299 final. Regarding mutual recognition and regulatory governance models, see M Maduro, We the Court - The European Court of Justice and the European Economic Constitution (Hart 1998).

11 Roth speaks of a 'trilemma' between the regulatory choice of applying the provisions of the host state (which would protect the regulatory policies of the host states, but gravely limit the access to the markets of those states), that of applying the provisions of the home state (which would promote the internal market, but might jeopardise the policies that a state may have in force to protect its legitimate and legitimately divergently-conceived public interest concerns), and finally that of pursuing a full harmonisation of rules limiting the fundamental freedoms (which would ensure a fully functional internal market, but might entail excessive costs and a too-high degree of centralization at the EU level). The author considers that mutual recognition can be regarded 'as a way out from this trilemma by pursuing all three approaches to some degree, but at the same time attempting to evade their disadvantages'. WH Roth, 'Mutual Recognition' in P Kourakos and J Snell (eds), Research Handbook on The Law of the EU's Internal 
a more general European administrative law perspective, mutual recognition has been studied as an instrument of 'transnational administrative law' and has also been considered as a stepping stone towards the creation of a truly 'integrated' European administrative space, ${ }^{12}$ giving rise to a system of transnationality of administrative decisions which was hitherto unknown in the EU. ${ }^{13}$ As a technique, it offers a middle ground between full centralization and integration in the EU decision-making area and the absolute application of the principle of national jurisdiction and territoriality.

Introduced as a regulatory technique by the Court of Justice in the context of the free movement of goods, the principle of mutual recognition has slowly found its way not only into the other fundamental freedoms and policy areas which are not strictly connected to the internal market, but has also been enshrined in more and more pieces of secondary legislation. ${ }^{14}$ Indeed, mutual recognition founded exclusively on the Treaty and the Cassis de Dijon premise would have to rely mostly on legal action taken by individuals who found their fundamental freedoms to be limited. ${ }^{15}$ For this reason, secondary legislation has increasingly complemented Treaty-based mutual recognition. Some of this legislation introduced harmonisation, standardisation and certification techniques aimed at achieving comparable results throughout the Member States, thereby facilitating the recognition of transnational effects on national de-

Market (Edward Elgar 2017) 429-430. Similar considerations are expressed in Pelkmans, 'Mutual Recognition: economic and regulatory logic in goods and services' (n5) 113-145.

12 M Gautier, 'Acte administratif transnational et droit communautaire' in JB Auby and J Dutheil de la Rochère (eds), Droit Administratif Européen (Bruylant 2014) 1303ff; JJ Pernas García, 'The EU's Role in the Progress Towards the Recognition and Execution of Foreign Administrative Acts: The Principle of Mutual Recognition and the Transnational Nature of Certain Administrative Acts' in J Rodriguez-Arana Muñoz (ed), Recognition of Foreign Administrative Acts (Springer 2016) 15-31; AS Gerontas, 'Deterritorialization in Administrative Law: Exploring Transnational Administrative Decisions' (2013) 19 Columbia Journal of European Law 423; H Hofmann, G Rowe and A Türk, Administrative Law and Policy of the European Union (OUP 2011) (who talk about 'transterritorial application of national decisions') 645ff; H Wenander, 'Recognition of Foreign Administrative Decisions' (2011) 71 Zeitschrift für ausländisches öffentliches Recht und Völkerrecht 755; L De Lucia, Amministrazione transnazionale e ordinamento europeo (Giappichelli 2009); G della Cananea, 'From the Recognition of Foreign Acts to Transnational Administrative Procedures' in J Rodriguez-Arana Muñoz (n12) 219; M Ruffert, 'Recognition of Foreign Legislative and Administrative Acts' (2011) Max Planck Encyclopaedia of Public International Law <http://opil.ouplaw.com/home/EPIL> accessed 6 September 2020; L De Lucia, 'Administrative Pluralism, Horizontal Cooperation and Transnational Administrative Acts' (2012) 2 Review of European Administrative Law 17; L De Lucia, 'From Mutual Recognition to EU Authorization: A Decline of Transnational Administrative Acts?' (2016) 1 Italian Journal of Public Law 90.

13 Hofmann, Rowe and Türk (n12) 8ff; Rodriguez-Arana Muñoz (n12).

14 See on this point Janssens (n4) chap 2.

15 De Lucia, 'From Mutual Recognition to EU Authorization: A Decline of Transnational Administrative Acts?’ (n12) 92. 
cisions. ${ }^{16}$ Besides, several secondary EU law measures have introduced various systems of mutual recognition which have given rise to so-called transnational administrative decisions, i.e. decisions which produce legal effects within the territory of other Member States or across the entire EU. ${ }^{17}$ As has been argued, and as the contributions to this special issue show, '[M]utual recognition as a legislative instrument is not a uniform concept. It rather appears in many variations. ${ }^{18}$ Indeed, it may be accompanied by different sets of reservations, it may be automatic, or embedded in a specific procedure.

Furthermore, as the contributions to this special issue highlight, mutual recognition is not a static concept in the history of EU integration which means that it is difficult to draw general conclusions from a specific set of cases. Sometimes, mutual recognition regimes have been replaced by systems in which the main decision-making or enforcement process takes place at the EU level (and is in the hands of the Commission or a Union agency). ${ }^{19}$ This typically happens when a system of national decision-making - supported by transnationality - is no longer able to achieve the policy objectives it was intended to meet, ${ }^{20}$ or if the decision-making process becomes too complex or generates over-protectionist tendencies on the part of the national authorities. ${ }^{21}$ In some cases, secondary legislation provides for a two-step decision-making procedure when the competence for the decision lies, prima facie, with the Member States, that may issue a transnational administrative decision. However, if another Member State (or the Commission) raises objections, it is up to the EU level to have the last say, issuing a final decision. In such regimes there is an incentive for cooperation (and mutual recognition can be regarded as a result of that cooperation) but, if such an incentive does not work, the competence is devolved to the Commission.

What is our contribution to this already rich debate? We propose a threefold contribution. Firstly, we take a fresh look at the 'classic' mutual recognition system in the context of free movement of goods, by considering the most recent trends and developments; secondly, we explore policy areas in which mutual recognition has been playing a role, but on which there has not yet been extensive research, such as the areas of pharmaceuticals, agriculture, social security

16 For an overview, see P Craig, 'The Evolution of the Single Market' in Barnard and Scott (n4) 1; Roth (n11) especially section C.

17 M Ruffert, 'The Transnational Administrative Act' in O Jansen and B Schöndorf-Haubold (eds), The European Composite Administration (Intersentia 2011) $277 \mathrm{ff}$.

18 Roth (n11) 439.

19 De Lucia, 'From Mutual Recognition to EU Authorization: A Decline of Transnational Administrative Acts?’ (n12) 90.

20 Roth (n11) 439.

21 De Lucia discusses this trend with reference to financial regulation and GMO governance in particular. De Lucia, 'From Mutual Recognition to EU Authorization: A Decline of Transnational Administrative Acts?’ (n12) 9०. 
and tax; and thirdly, by acknowledging that mutual recognition is not a peculiarly EU regulatory technique, we consider one national experience of mutual recognition, the peculiar features of which could help to shed some light on the foundations and operation of mutual recognition at the supranational level.

\section{The principle of mutual recognition in the EU legal order}

This special issue analyses the system of mutual recognition in various regulatory contexts. After a more general examination concerning the free movement of goods (De Lucia), it focuses on the use and development of mutual recognition in specific sectors, namely driving licences (Schröder), pharmaceuticals (Röttger-Wirtz), social security (Wenander), tax (Dorigo), and agriculture (Volpato). Finally, it contains a national contribution, which highlights how mutual recognition can operate in the context of a national multilevel administrative system such as the Spanish one (Arroyo-Jiménez).

The papers collected in this special issue reveal three common lines. The first is that the role and importance of mutual recognition, as such, vary considerably from sector to sector and even within a specific area, depending on the different weight attached to the values of the internal market compared to other values considered worthy of protection. Secondly, mutual recognition often appears to be side-tracked in the face of both EU and national interests. Finally, because of the side-tracking of mutual recognition in certain policy fields, alternative forms of cooperation, coordination procedures, or harmonization between the various national systems are progressively emerging. On the one hand, the EU has increasingly preferred establishing systems in which the decisionmaking power belongs to the EU level (in the hands of the Commission or of a Union agency) or results from composite procedures. At the same time, on the other hand, the defence of various public interests of the Member States without the ability to reach a compromise acts as a catalyst for side-tracking mutual recognition. Mutual recognition is the result of cooperation between the Member States: when the will to cooperate is not strong enough to overcome the national interest, the system is no longer capable of delivering results and an alternative solution must be found.

\subsection{The multi-faceted nature of mutual recognition}

The papers of this special issue clearly show that mutual recognition is neither a univocal nor a static concept.

First of all, the role of mutual recognition varies considerably from sector to sector. It has a more relevant role in those sectors in which fundamental freedoms are at stake (such as the free movement of goods and the recognition of driving licences), while it appears to be less relevant or possibly progressively 
losing importance in those fields in which the protection of general interests that affect the sovereignty of the Member States remains strong (this is the case of tax, social security and pharmaceuticals).

Furthermore, in the fields in which mutual recognition plays a role, its regimes can also be quite different and have evolved over time.

De Lucia, with general reference to the free movement of goods, observes that mutual recognition is still 'highly significant', but he points out that it is governed by at least three models: (a) mutual recognition under the Treaty and interpreted by the Court of Justice; (b) transnational administrative authorisations; and (c) certifications of conformity, issued by notified bodies. ${ }^{22}$ Although all these models protect the free movement of goods, they present significant differences, namely in terms of market governance, sources (with a central role played the Court of Justice in the first model, and of the European legislator in the second and third one), the relationship between the EU and the Member States, and the number and weight of administrative cooperation procedures that accompany the actual mutual recognition. The picture, in short, appears fragmentary and fluctuating, to the point that De Lucia claims that 'in this area the principle of mutual recognition has more symbolic than heuristic value'. ${ }^{23}$

In the field of mutual recognition of driving licenses, Schröder explains that mutual recognition is an important principle, but again there is no one single model to implement it. From the initial jurisprudence of the Court of Justice, which emphasized the need for mutual trust as a prerequisite for the correct functioning of mutual recognition, the regime has evolved through various directives, which tried to balance the aims of mutual recognition with the protection of the Member States' interests. Schröder also notes the importance of harmonisation as a basis for mutual trust (and consequently mutual recognition) in the area of 'circulation' of driving licences. The fact that common standards for the issuing of driving licences are established at EU level makes it easier for a Member State to recognise documents issued by a different legal system. The various forms that mutual recognition has taken over time demonstrates the continuous effort to balance the free movement imperative with the political need to make recognition acceptable in the Member States.

The contributions collected in the special issue also show that mutual recognition plays less of a role in areas in which the Member States' interests remain predominant, both for the protection of national interests and for the defence of weaker parties.

In the context of the recognition of authorizations for the marketing of pharmaceutical products, Röttger-Wirtz confirms that Member States are 'very

\footnotetext{
22 L De Lucia, 'One and Triune - Mutual Recognition and the Circulation of Goods in the EU' (2020) 3 Review of European Administrative Law 33.

23 ibid 33.
} 
reluctant with regard to automatic mutual recognition', given the high sensitivity of the matter. ${ }^{24}$ Therefore, the various procedures followed for marketing authorizations - particularly the Mutual Recognition Procedure and the Decentralized Procedure - aim at allowing recognition of the assessment made by the home state, thus avoiding that the national authorities take diverging decisions for the same product. However, the basis for mutual recognition ultimately lies in the participation of states throughout the entire procedure, so that, as RöttgerWirtz notes, 'the mutual recognition principle as understood in the sense of a Dassonville-like automatic mutual recognition has been denied and only introduced in a weakened form within the safety-net of a composite procedure', which ultimately depends on the level of agreement between the Member States. $^{25}$

The principle of mutual recognition also seems to have a limited scope of application in the social security sector. This is a sector of high sensitivity, in which, as Wenander notes, the states jealously defend their prerogatives and are, therefore, reluctant to accept the penetration of acts coming from another system. Coordination is, therefore, the main form of cooperation, in the absence of forms of harmonization. The only area in which mutual recognition plays a major role is that of the circulation of certificates issued by a foreign authority which are relevant in social security matters.

Wenander's contribution also shows that cooperation is a means of strengthening mutual recognition, which often could not be realized in the absence of some form of prior participation of Member States in the procedure leading up to recognition. A relevant role in this system of cooperation is played by mechanisms of exchange of information, which characterize both the free movement of goods and the social security sector. With respect to the latter area, Wenander even speaks of an 'administrative network'.

Again, the scope for mutual recognition is quite limited in tax matters, as Dorigo argues in his paper. Just as in the social security field, in the tax area, mutual recognition is applicable to limited situations - the case of the recognition of certificates of residence - nor has harmonization of substantive tax conditions been realized, or only marginally. The defence of the national tax systems, which is directly related with political choices and, therefore, with electoral success, also puts the instrument of procedural coordination between the Member States in the foreground.

Finally, the common agricultural policy (CAP) is a special sector. Volpato points out that this is a highly centralised sector, in which, therefore, the autonomy of the Member States has been until now very limited, and with it

24 M Schröder, 'Mutual Recognition of Driving Licences in the EU - Current State of Integration and Perspectives' (2020) 3 Review of European Administrative Law 37.

25 S Röttger-Wirtz, 'Mutual recognition and the ever-incomplete internal market for pharmaceuticals' (2020) 3 Review of European Administrative Law 63. 
mutual recognition as well. However, the recent legislative evolution of the CAP shows that we are "moving from a "vertical" to a "horizontal" form of harmonisation and progressively expanding the role of the Member States in the regulation of this important sector'. ${ }^{26}$ As a consequence, there is scope for mutual recognition (for example with regard to the circulation of certificates of origin), which becomes 'an instrument of positive integration which is enacted by the EU legislator for the functioning of the internal market and which concurs to the development of a European administrative space'. ${ }^{27}$

\subsection{The side-tracking of mutual recognition}

The contributions in this special issue show that mutual recognition appears to be side-tracked in the face of both EU and national interests.

In those fields in which the role of mutual recognition is still wide (i.e. the free movement of goods and driving licences), a Member State can limit mutual recognition in order to adequately protect its internal public interests.

Hence, De Lucia stresses that the limit to mutual recognition posed by the defence of national interests characterises all three forms of mutual recognition analysed, while in the case of driving licences, Schröder emphasises the need to avoid driving licence tourism. With regard to driving licences, the legislation in force establishes an obligation for the state of normal residence to refuse to issue a driving licence to an applicant whose driving licence is restricted, suspended or withdrawn in another Member state, while other Member States have a duty to refuse recognition of a driving licence issued by another Member State to a person whose driving licence is restricted, suspended or withdrawn in the former state's territory.

Both authors emphasise the role of the case-law of the Court of Justice in outlining cases where the public interest may allow non-recognition. ${ }^{28}$ In this sense, the exceptions are interpreted strictly, in order to avoid that free movement be overly restricted.

Outside these cases, it seems that the limits to mutual recognition are interpreted in a wider fashion, in line with the need to protect highly sensitive areas and to guarantee fundamental national interests.

Thus, in the field of tax law, Dorigo points out that the defence of national interests is the natural consequence of the relevance of taxation for the definition of domestic public policies, namely, the coverage and functioning of the welfare state. It is precisely this aspect that leads to a preference for alternative forms of coordination, so as to protect the choices of national governments. With regard

26 A Volpato, 'Mutual recognition, Pre-emption and De-centralisation in the

Common Agricultural Policy' (2020) 3 Review of European Administrative Law 139.

27 ibid 157 .

28 On this point see also the contribution of Möstl (n5) 405. 
to the mutual recognition of certificates of residence, the author shows that this aim is fulfilled through the possibility for the national administration to disregard the content of the foreign certificate, adding concrete evidence that the certificate is inaccurate. ${ }^{29}$

In tax law and in social security coordination, the scope for mutual recognition - which is in itself limited because of political sensitivity - is destined to be further restricted in order to protect the integrity of the internal legal system.

With regard to the pharmaceutical area, Röttger-Wirtz's analysis shows that the limit to mutual recognition is the emergence of 'potential serious risks to public health'.$^{30}$ The limits to such an exception are delineated by the Court of Justice, which 'has taken a measured approach towards the Member States discretion in deviating from mutual recognition, respecting their autonomy to protect public health while strictly enforcing the limits of non-recognition as enshrined in the procedural framework. ${ }^{31}$

In the context of circulation of agricultural products, Volpato notes that where there is room for mutual recognition - this happens without Member States being allowed a defensive margin of appreciation. Thus, 'certificates on organic production issued by a national competent authority are recognised throughout the Union, qualifying as automatically transnational administrative acts. ${ }^{32}$ However, this situation is undoubtedly influenced by the high degree of centralisation of the regulatory framework in this particular sector: it seems that the responsibility to balance the recognition of these certificates and the protection of the health and life of humans, animals, or plants (according to art. 36 TFEU) is fully realized by the EU legislator, leaving aside any role for national authorities in this field.

Furthermore, the regulatory landscape also foresees forms of coordination of possible contentious phases. This situation happens, for example, in the pharmaceutical sector, where Röttger-Wirtz notes the role of the Co-ordination Group for Mutual Recognition \& Decentralized Procedures - Human, composed of one representative per Member State, with the Commission as an observer, which tries to reach consensus in case a State raises concerns about the risks for public health in order to deny recognition. Should consensus-building in the Co-ordination Group fail, a further arbitration step is established on a supranational level 'at the European Medicines Agency, where the main scientific committee will provide an opinion' to resolve differences in assessment between the various states involved. This opinion is subsequently forwarded to the EU

29 S Dorigo, 'Mutual recognition versus transnational administration in tax law: is fiscal sovereignty still alive?' (2020) 3 Review of European Administrative Law 111.

30 Röttger-Wirtz 72.

31 Volpato 137.

32 ibid 156. 
Commission, 'which will adopt a decision that is binding upon the Member States. ${ }^{33}$

A similar form of arbitral dispute resolution can also take place in tax law: Dorigo observes that the recent Directive 1852/2017 on the mechanisms for resolving tax disputes in the European Union provides for a system in which the competent tax administrations of the two (or more) states involved are able to reach the binding definition of a tax claim. ${ }^{34}$

\subsection{The emerging alternatives to mutual recognition}

The weight that national interests continue to have in the various sectors concerned explains why mutual recognition is accompanied (in some cases) or replaced (in others) by alternative methods of coordination.

Where there is a lack of harmonisation, the mutual trust that underpins mutual recognition seems to weaken and there is, therefore, a need for States to identify instruments capable, at least in the abstract, of cementing such mutual trust. To this end, the EU has increasingly established systems in which decision-making power ultimately resides at EU level (in the hands of the Commission or of a Union agency) or results from composite procedures.

With regard to pharmaceuticals, Röttger-Wirtz mentions the so-called Centralised Procedure which takes place fully at EU level, although she emphasises that its role is still limited if compared to that played by the two other national - authorisation procedures. ${ }^{35}$

With regard to the free movement of goods, De Lucia recalls that the EU legislator has increasingly provided for joint decisions, i.e. 'national authorization[s] which [are] the result of a composite procedure, in which all the State administrations involved participate with a co-decisional role'. ${ }^{36}$

In the case of taxation, procedural coordination seems to be the emblem of overcoming mutual recognition tout court, as Dorigo points out, noting that tax law is a field where a new paradigm, already proposed in theory by administrative law scholars, is concretely emerging: a field where we are witnessing the fading of theories based on mutual recognition in favour of a system built on transnational administrative procedures, no longer founded on the circulation of acts issued by a single system, in which only the final part (that of recognition) calls for the intervention of another State.

\footnotetext{
Röttger-Wirtz 73 .

Dorigo 130.

Röttger-Wirtz 73 .

De Lucia 7.
} 
Instead, what is emerging is a system of procedures that 'through the full and equal participation of the administrations involved leads to the identification of a single act, effective as such in all the States concerned'. ${ }^{37}$

In the field of social security, the paradigm is that of coordination, as noted by Wenander, with particular reference to the establishment of a special EU body - the Administrative Commission for the Coordination of Social Security Systems - composed by representatives of each Member State and 'dealing with questions of administration and interpretation, facilitating the uniform application of EU law, and fostering and developing cooperation between Member States and their social security institutions' ${ }^{38}$

The coordination of proceedings also seems to be established in those contexts less characterised by the defence of special public interests. According to Volpato, even in a largely centralised sector such as that of CAP, space must be given to 'relational and collaborative' forms. ${ }^{39}$

In general, the contributions of this special issue show that, particularly in those contexts characterized by a greater sensitivity to the values at stake, one can observe that mutual trust is increasingly coexisting with or being replaced by procedures in which the Member States can participate on equal terms, so that the protection of national interests is evaluated and balanced from the outset.

\subsection{Mutual recognition beyond the EU context}

The special issue highlights a special case concerning the Spanish practice of mutual recognition in the internal sphere. As explained by Arroyo-Jiménez, in Spain, mutual recognition among regions is not provided for in the Constitution; rather, it is left to the will of specific regional authorities or to state legislation: in the latter case, however, the Constitutional Court has made clear that mutual recognition obligations can only be established on a sectoral basis and if the home and host regulatory policies protect the relevant public interests in a similar manner. This is an important difference with the law of the EU internal market, according to which mutual recognition can also arise from the Treaty, and for which equivalence is sometimes not a precondition. Another difference with EU law is that, in Spain, mutual recognition is always both absolute and passive, i.e. it does not authorize an exception to the obligation to recognize administrative decisions taken by the authorities of a different region, and it does not need a specific recognition procedure by the host authorities. Arroyo-Jiménez holds that the disparities regarding the

37 Dorigo 135

38 H Wenander, 'Sincere Cooperation, Mutual Trust, and Mutual Recognition in Social Security Coordination' (2020) 3 Review of European Administrative Law 96.

39 Volpato, 159. 
foundation, scope, and mode of operation of mutual recognition in EU and in Spanish law are connected with the way in which regulatory powers are shared among the various levels of government, the diverse risk of market fragmentation, and the effectiveness of other coordination and harmonization powers.

Further research should be carried out to investigate the role and functioning of mutual recognition in other multi-level administrative systems within the EU..$^{40}$ The Spanish case-study shows that they are not only useful in order to understand how this regulatory strategy operates in other legal orders; rather, they also provide a useful point of comparison to better understand the role and functioning of mutual recognition within EU law itself.

\section{Conclusions}

Mutual recognition has been considered as a 'differentiated instrument varying with regard to the area in which it is applied, depending on the degree of harmonization that has been reached, and with regard to potential countervailing interests that have to be taken into account'. ${ }^{41}$ The contributions to this special issue indeed confirm the multi-faceted nature and dynamic of mutual recognition and its variations within specific policy fields. Our contributions also seem to support both those critical voices which have expressed doubts on whether the system of mutual recognition is still fit for purpose, ${ }^{42}$ and, to some extent, those which have observed increasingly centralising tendencies in the EU regulatory framework. ${ }^{43}$

Where does our special issue leave the development of a 'transnational European administrative space' fostered by horizontal cooperation and, especially, mutual recognition? It is not predictable, at present, what the role of mutual recognition in the EU legal system will be in the future. The uncertainty as to its current role, as envisaged in all the contributions to the present special issue, suggests caution. What emerges is that mutual recognition as such is hardly a viable solution without prior harmonization or other forms of cooperation - both during and after the administrative procedures - between the Member States concerned. Mutual trust is not unconditional, even in the EU area, and mutual recognition needs to be supported by EU or supranational instruments to function effectively. As mutual recognition depends on the co-

\footnotetext{
See eg the book by P Starski, Der interföderale Verwaltungsakt (Mohr Siebeck 2014).

Roth (n11) 458-459.

ibid 459; Weatherhill (n5) 224.

43 eg Roth gives the example of financial regulation, (n11) 429. De Lucia also gives the examples of the setting up of the European Railway Agency and the regulation of novel food, De Lucia, 'From Mutual Recognition to EU Authorization: A Decline of Transnational Administrative Acts?' (n12) 90.
} 
operation between Member States in areas in which they have discretionary decision-making powers, in the absence of centralization by the EU, it may suffer from centrifugal or centripetal forces becoming predominant in a given policy field.

One final concluding remark: the focus of this special issue has been on the functioning of mutual recognition as a regulatory technique. However, beyond this exploration lies a wide unchartered territory, namely the concrete problems arising at the national level with respect to the operation of mutual recognition and, especially, its judicial treatment. Further research should be dedicated to investigating how national courts concretely deal with mutual recognition situations and what challenges this poses to the system of European integrated administration. 